\title{
Adapting the Fire-Grazing Interaction to Small Pastures in a Fragmented Landscape for Grassland Bird Conservation
}

\author{
Authors: Courtney J. Duchardt, James R. Miller, \\ Diane M. Debinski, and David M. Engle
}

NOTICE: this is the author's version of a work that was accepted for publication in Rangeland Ecology and Management. Changes resulting from the publishing process, such as peer review, editing, corrections, structural formatting, and other quality control mechanisms may not be reflected in this document. Changes may have been made to this work since it was submitted for publication. A definitive version was subsequently published in Rangeland Ecology and Management, VOL\# 69, ISSUE\# 4, (July 2016) DOI\# 10.1016/j.rama.2016.03.005.

Duchardt, Courtney J., James R. Miller, Diane M. Debinski, David M. Engle. 2016. Adapting the Fire-Grazing Interaction to Small Pastures in a Fragmented Landscape for Grassland Bird Conservation. Rangeland Ecology \& Management, 69(4), 300-309. Available at: http:// dx.doi.org/10.1016/j.rama.2016.03.005.

Made available through Montana State University's $\underline{\text { ScholarWorks }}$ scholarworks. montana.edu 


\title{
Adapting the Fire-Grazing Interaction to Small Pastures in a Fragmented Landscape for Grassland Bird Conservation
}

\author{
Courtney J. Duchardt a,*, James R. Miller ${ }^{\mathrm{a}, \mathrm{b}}$, Diane M. Debinski ${ }^{\mathrm{c}}$, David M. Engle ${ }^{\mathrm{d}}$ \\ ${ }^{a}$ Department of Natural Resources and Environmental Sciences, University of Illinois as Urbana-Champaign, Urbana, IL 61801 USA \\ ${ }^{\mathrm{b}}$ Graduate Program in Ecology, Evolution, and Conservation Biology, University of Illinois as Urbana-Champaign, Urbana, IL 61801 USA \\ ${ }^{c}$ Department of Ecology, Evolution and Organismal Biology, Iowa State University, Ames, IA 50011 USA \\ ${ }^{\mathrm{d}}$ Department of Natural Resource Ecology and Management, Oklahoma State University, Stillwater, OK 74078 USA
}

\begin{abstract}
A B S T R A C T
In North America, the loss of habitat heterogeneity resulting from homogeneous livestock grazing is one factor contributing to steep population declines of many grassland bird species. Patch-burn grazing is a management technique that uses historic grassland disturbance as a model to create heterogeneous grassland composition and structure, providing for the diverse habitat requirements of grassland birds. Though this management technique has been used successfully in relatively extensive grasslands, its utility on smaller grassland patches is less clear. We examined the efficacy of patch-burn grazing to restore habitat heterogeneity and increase grassland bird diversity in relatively small pastures (15-32 ha) in a grassland landscape fragmented by cultivation and tree encroachment. In 2006, we established 12 experimental pastures in the Grand River Grasslands of southern Iowa and northern Missouri, with 4 pastures in each of three treatments: 1) patch-burn graze, with spatially discrete fires and free access by cattle (the fire-grazing interaction), 2) graze-and-burn, with free access by cattle and a single burn of the entire pasture every third year, and 3) burn-only, with a single burn of the entire pasture every third year and no grazing. Patch-burn grazing in the first phase of the project (2007-2009) did not generate habitat heterogeneity or significant differences in bird diversity. From 2010 to 2013, stocking rates were reduced to increase residual vegetation in unburned patches at the end of the grazing season to increase heterogeneity. Habitat heterogeneity in patch-burn graze pastures subsequently increased relative to other treatments. Concomitantly, diversity of obligate grassland birds also increased in patch-burn graze pastures and was greatest in 2012 and 2013. We conclude that the fire-grazing interaction can be used to restore habitat heterogeneity and increase grassland bird diversity, even in relatively small grassland patches embedded in a highly fragmented landscape.
\end{abstract}

\section{Introduction}

Grassland bird populations in North America have experienced some of the steepest and most widespread declines among all avian guilds (Knopf, 1994; With et al., 2008; Sauer et al., 2011), largely as a result of habitat conversion to agricultural uses (Knopf, 1994; Brennan and Kuvlesky, 2005; Askins et al., 2007; With et al., 2008). With grassland conversion to cultivated land, grassland obligate birds are virtually eliminated because cropland provides habitat for only a few generalist species (Best et al., 1995, 1997). Grassland birds have also been

\footnotetext{
is Funding for this project was through the State Wildlife Grants program grant U-2-R-1 in cooperation with the US Fish and Wildlife Service and Wildlife and Sport Fish Restoration Program.

* Correspondence: Courtney J. Duchardt, University of Wyoming, Agriculture Building 2015, 1000 E University Ave, Laramie, WY 82071 USA. Tel: + 1-816-582-1450. E-mail address: cduchard@uwyo.edu (C.J. Duchardt).
}

adversely affected by anthropogenic use and management on the $<1 \%$ of historic tallgrass prairie that remains in the Midwest (Samson and Knopf, 1994), mainly through the cessation or severe alteration of historic disturbance regimes, including fire and grazing.

Before European settlement, North American grasslands were maintained by frequent and intense disturbance (Brawn et al., 2001), primarily through the interaction of fire and grazing by large native herbivores. This fire-grazing interaction occurred when patchy fires led to focal grazing on nutrient-rich regrowth in recently burned areas, coupled with a concurrent release of unburned areas from grazing (Fuhlendorf and Engle, 2001; Anderson, 2006). Over time, heavily grazed areas were abandoned for newly burned patches, resulting in a shifting mosaic of heterogeneous vegetation structure across the landscape (Fuhlendorf and Engle, 2004). Grassland birds adapted to the niches present in this heterogeneous mosaic, and avian biodiversity was contingent upon spatial heterogeneity (Knopf, 1996). Unfortunately, conventional rangeland management in the United States aims to reduce 
bare ground and increase desirable forage ("managing for the middle"; Fuhlendorf et al., 2012). This principle necessarily promotes homogeneity through spatially uniform, moderate utilization (Holechek et al., 2010; Fuhlendorf et al., 2012). In the eastern Great Plains, pervasive heavy grazing pressure engenders habitat homogeneity on par with cropland (Engle et al., 2008a; Miller et al., 2012), accommodating only a few species that tend to be fairly widespread (Fuhlendorf et al., 2009). In the central and western Great Plains, as well as the more arid rangelands throughout western North America, grazing management fosters homogeneity by minimizing discrete disturbances through uniform distribution of cattle in time and space (Fuhlendorf and Engle, 2004; Holechek et al., 2010). Considering plummeting populations of grassland birds (Sauer et al., 2011) and the small proportion of remaining habitat in the Midwest (Samson and Knopf, 1994), identifying and promoting appropriate rangeland management that considers the importance of these historic disturbances for grassland birds is crucial (Powell, 2006).

One technique that has been used to successfully sustain avian diversity on grasslands is patch-burn grazing. Patch-burn grazing employs an understanding of historic disturbance regimes, using discrete burns and cattle grazing to maintain structural heterogeneity on grasslands. Relative to traditional grazing management, the patch-burn grazing framework enhances species diversity for a variety of taxa, including grassland birds (Fuhlendorf et al., 2006; Engle et al., 2008b; Fuhlendorf et al., 2010). Much of the published research on patch-burn grazing and grassland birds has been conducted in relatively large pastures (>400 ha) in Oklahoma (Fuhlendorf et al., 2006; Coppedge et al., 2008). In 2006, we initiated a study in a suite of pastures that were an order of magnitude smaller than the Oklahoma study, embedded in a highly fragmented landscape. One might expect different results under these conditions for a variety of reasons. There is the potential of an area-heterogeneity trade-off (Allouche et al., 2012; Bar-Massada and Wood, 2014; Stein et al., 2014), as relatively small pastures are further subdivided by patch burning. This trade-off could be exacerbated in highly fragmented landscapes by factors including habitat isolation when the matrix is not dominated by native grassland (Herkert, 1994; Winter et al., 2006; Ribic et al., 2009b), as well as edge-effects along borders with cropland, woodland, or roads (Bollinger and Gavin, 2004; Ries et al., 2004; Renfrew et al., 2005).

Indeed, results from the first phase of our study (2007-2009) showed that avian diversity on patch-burn graze pastures was not different from that observed on homogeneity-based treatments (Pillsbury et al., 2011). Although multiple factors may have influenced these results (McGranahan et al., 2012b), heterogeneity within patchburn graze pastures was unexpectedly low (Pillsbury et al., 2011). We attributed this result to heavy stocking because grazing lawns were not restricted to the recently burned patch. Overstocking of cattle throughout the grazing season (late April through October) led to heavy grazing on the burn patch early in the season followed by an eventual shift of cattle grazing to unburned patches and, therefore, uniform grazing across the pasture (Scasta, 2014). Beginning in 2010, we reduced stocking rate to increase residual vegetation at the end of the grazing season as a means of increasing habitat heterogeneity on these pastures. Here, we use data collected from 2010 to 2013 to test the following hypotheses:

1) Stocking rate is a key driver of pasture-scale habitat heterogeneity. Prediction: reduced stocking rate will increase habitat heterogeneity on patch-burned pastures.

2) Pasture-scale habitat heterogeneity is the primary determinant of local avian diversity. Prediction: the diversity of bird species will increase in response to increased heterogeneity in vegetation structure on patch-burn pastures, overriding the effect of withinpasture variation in other habitat features and pasture size.

3) The effect of habitat heterogeneity at local scales is constrained by land cover patterns at broader scales. Prediction: Increased diversity of avian communities in response to increased heterogeneity within pastures will be mitigated by decreased amount of grassland in the surrounding landscape.

\section{Methods}

\section{Study Design}

In 2006, we delineated 12 experimental pastures in the Grand River Grasslands, a region comprising 30,000 ha in Ringgold County, Iowa, and Harrison County, Missouri (Pillsbury et al., 2011). The Grand River Grasslands have been identified as the best known opportunity to restore a functioning tallgrass prairie ecosystem (TNC, 2008), due to the relatively large area in native and non-native grasses ( $>80 \%$ ) and the amount of land that is protected (15\%). Although this landscape contains a large amount of tallgrass prairie habitat, it represents a more fragmented landscape than most patch-burn graze studies to date (e.g., Tallgrass Prairie Preserve; Fuhlendorf et al., 2006; Fuhlendorf et al., 2009) (Fig. 1).

Dominant native plants on study pastures included little bluestem (Schizachyrium scoparium), rough dropseed (Sporobolus clandestinus), Canada goldenrod (Solidago altissima), and sedges (Carex spp.; McGranahan et al., 2013). Dominant exotic plants included the invasive Eurasian grass tall fescue (Schedonorus arundinaceous), as well as smooth brome (Bromus inermis) and bird's-foot trefoil (Lotus corniculatus). The predominant land cover surrounding these pastures was grassland (58\%), comprising pastures, hayfields, and native prairie. The remainder consisted mainly of woodlands (22\%) and row crops (18\%; Lyons, 2013).

Study pastures ranged in size from 15 to 32 ha. In 2007, each pasture was divided into three patches of approximately equal area. Pastures were then assigned to one of three treatments ( $n=4$ pastures per treatment): 1) patch-burn graze, 2) graze-and-burn, and 3) burn-only. The patch-burn graze treatment was designed to increase within-pasture heterogeneity by burning one patch annually with a fire return interval of 3 years for each patch and free access to the entire pasture for cattle. The graze-and-burn treatment consisted of one pasture-wide burn every 3 years with free access for cattle. The burn-only treatment consisted of one pasture-wide burn every 3 years and no grazing. The latter treatment was representative of protected area management in the region at the time the study was initiated. The graze-and-burn treatment was intended to represent more homogeneous application of fire and grazing. Pasture-wide burns were conducted in 2009 and 2012. Although burning was rare on private land, it was necessary on our study pastures to mitigate encroachment of woody species and to maintain a 3-year fire return interval across all treatments. Grazed pastures were fenced only along their perimeters.

From 2007 to 2009, stocking rate on grazed pastures averaged 3.1 animal unit month (AUM) ha ${ }^{-1}$. Stocking rate was reduced in 2010 and 2011 to 1.7 AUM ha $^{-1}$ to increase heterogeneity among patches on patch-burn graze pastures. Beginning in 2012, stocking rate of each pasture was adjusted annually to an average of $2.5 \mathrm{AUM} \mathrm{ha}^{-1}$ on the basis of plant biomass remaining at the end of the previous grazing season.

\section{Avian Surveys}

To survey the avian community, we established one to three line transects in each patch (3-9 transects per pasture). Each transect was between 100 and $300 \mathrm{~m}$ in length depending on pasture size. Transects were divided into $100-\mathrm{m}$ subsections and were placed to maximize the amount of grassland habitat surveyed. Distance between transects was at least $150 \mathrm{~m}$, and observations were confined to individuals within $50 \mathrm{~m}$ to avoid double-counting individual birds. Each transect was at least $50 \mathrm{~m}$ from patch edges to avoid counting birds outside patch boundaries. Universal Transverse Mercator (UTM) coordinates were recorded at the start and end points of each transect subsection, and 


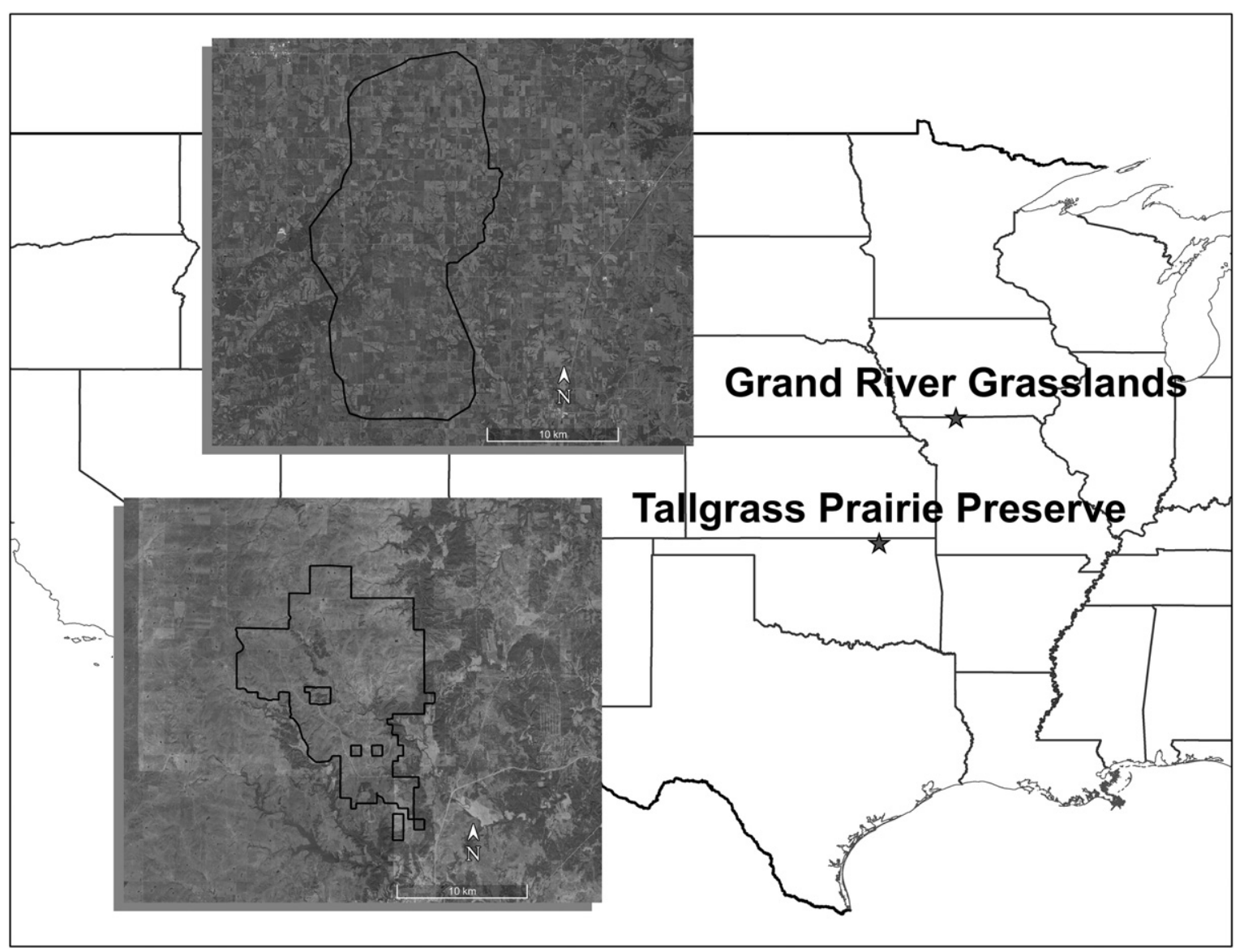

Figure 1. Landscape-scale fragmentation within the Tallgrass Prairie Preserve, Oklahoma, and the Grand River Grasslands of Missouri and Iowa.

Global Positioning System units were used to relocate these points on subsequent surveys.

We surveyed each pasture every 2 weeks during each field season (15 May - 30 July) from 2010 to 2013, using methods similar to those employed in the first phase of the project (Pillsbury et al., 2011). Surveys were conducted on calm days with no rain between 0600 and $1000 \mathrm{~h}$, when grassland birds are most active (Ralph et al., 1993). A single observer recorded all birds seen and/or heard, noting the species, group size, and sex when possible. Observers were trained and tested on field identification before the initiation of surveys and were rotated during each field season to minimize observer bias.

\section{Vegetation Surveys}

We quantified within-pasture habitat features by measuring vegetation composition in July of each year using $900.5-\mathrm{m}^{2}$ quadrats in each experimental pasture (30 quadrats per patch). We placed quadrats parallel to bird transects at a distance of $25 \mathrm{~m}$ on either side. Within each quadrat, we estimated percent canopy cover of warm-season grasses, cool-season grasses, forbs, legumes, and woody species and cover of litter and bare ground. Percent cover was recorded as the midpoint of the following categories: $0,1-5,5-25,25-50,50-75,75-95,95-100$ (Daubenmire, 1959). Given the dominance of tall fescue and its potential to negatively influence survival within the avian community (Barnes et al., 1995; Hovick et al., 2011; Lyons et al., 2015) and interfere with the fire-grazing interaction (McGranahan et al., 2012a), percent canopy cover of this invasive cool-season grass was recorded separately. Visual obstruction, a metric incorporating both vegetation height and density, was measured using a Robel pole placed at the center of each quadrat (Robel et al., 1970). From a distance of $4 \mathrm{~m}$ in each cardinal direction, we recorded the highest point at which the pole (marked in $10-\mathrm{dm}$ intervals) was obscured $50 \%$ or more.

\section{Landscape Metrics}

Habitat selection has been described as a hierarchical process for birds, and avian habitat use is influenced by the surrounding landscape matrix (Hutto, 1985; Cunningham and Johnson, 2006; Davis et al., 2013); therefore, we quantified landscape composition proximate to our experimental pastures. Land-cover types within a $1-\mathrm{km}$ buffer of each pasture were identified and digitized in ArcGIS using 2011 digital orthophotos (US Department of Agriculture 2011) using the following land-cover types: 1) woodland, 2) grassland, and 3) row crop. Specifically, we were interested in landscape effects at two spatial scales, within $300 \mathrm{~m}$ and $1000 \mathrm{~m}$. We analyzed landscape effects at two different distances because species may exhibit variable responses to land cover at different scales (Cunningham and Johnson, 2006). These two scales were selected to replicate the spatial scales analyzed by Pillsbury et al. (2011); the 300-m scale represents a "meso-scale" of habitat immediately surrounding the pasture (Warren et al., 2005), while the 1000-m scale represents the points at which no additional variation in this landscape was captured (Pillsbury et al., 2011).

\section{Data Analyses}

Our primary metric of heterogeneity, "patch contrast," was calculated as the standard deviation of the three patch-level values of visual obstruction per pasture. To accommodate mean-variance scaling, we used the log of each patch-level value in calculating standard deviation (McArdle et al., 1990; Fraterrigo and Rusak, 2008). We expected heterogeneity to be greatest in patch-burn graze pastures as a function of the 
fire-grazing interaction and reduced stocking rates. Conversely, grazeand-burn and burn-only pastures were expected to yield relatively low values of patch contrast. We included an additional measure of heterogeneity within pastures, the log-adjusted standard deviation of the three patch-level values of litter cover. Litter cover, like visual obstruction, is a function of disturbance frequency and can influence habitat use by grassland birds (Swengel and Swengel 2001; Fisher and Davis, 2010).

We calculated an index of observed density of all obligate and facultative grassland bird species. Following Vickery et al.'s (1999) definitions, obligate grasslands birds are species that are entirely dependent on grassland habitat, while facultative species use grasslands but are not entirely reliant on grassland habitat. Observed density was defined as the maximum number of individuals detected in a pasture during the breeding season divided by the area sampled; this metric was used mainly to allow direct comparison between this study and methods used in the first phase of the project (Pillsbury et al., 2011). However, calculating observed density via repeated surveys in each pasture allowed us to capture the temporal window when individual bird species were most abundant, given phenological differences among bird species. Although passive sampling (Ribic et al., 2009b) has been implicated as a potential issue when conducting surveys in patches of differing size, we did not directly adjust for passive sampling (e.g., subsampling transects) in these analyses for two reasons. First, random subsamples poorly represented the avian community in large patches because pastures were heterogeneous in topography and vegetation composition. Second, we included pasture size as an explanatory variable in the following analyses; if passive sampling was indeed influencing our results, we would expect pasture size to explain a large amount of variation in avian diversity (see results).

We quantified species richness $(\mathrm{S})$ and Shannon diversity $\left(\mathrm{H}^{\prime}\right)$ of the overall avian community and for obligate species (sensu Vickery et al., 1999 ) by pasture. To compare these diversity measures among treatments, we used a mixed model (Proc MIXED, SAS 9.2), with year and treatment as fixed effects and pasture as a repeated measure.

To better understand how within-pasture habitat features and landscape-level effects may mitigate the influence of treatment on diversity, we used generalized linear models (PROC GENMOD, SAS 9.2) to compare the effects of these variables on overall and obligate diversity. We first generated single-variable models for three model groups (treatment, habitat, landscape) representing variables of interest (see Appendix for full model sets). We also included a fourth model group representing the "nuisance" variables of pasture size and year, as both of these variables have the potential to strongly influence diversity regardless of management. We then ranked all of these models using Akaike's Information Criterion adjusted for small sample sizes ( $\mathrm{AIC}_{\mathrm{c}}$; Anderson, 2008). We took the top model from each model group and combined these into all two-, three-, and four-way model combinations.

Complementing univariate analyses of diversity, we further assessed variation in avian community structure among treatments using permutational multivariate analysis of variance (PerMANOVA; Anderson, 2001). PerMANOVA is a nonparametric analogue to MANOVA in which variance is partitioned to generate a test statistic (comparable with the F-statistic in ANOVA), and permutational methods, which do not require parametric assumptions, are used to generate $P$ values. We tested the effects of both treatment and year on community structure using the Adonis function in R (Oksanen et al,. 2011).

To examine community dissimilarity among pastures and years, we implemented nonmetric multidimensional scaling (NMDS; Kruskal, 1964) using the Vegan function in R (Oksanen et al., 2011). NMDS is an unconstrained ordination technique that is especially robust to non-normal data and allowed us to compare treatments by graphically differentiating pastures in ordination space. The ordination plot is based on rank-order dissimilarity of sets of multivariate data (here, avian community composition for each pasture in each year); therefore two pastures with similar communities will be located near one another in ordination space. An iterative procedure, NMDS uses an algorithm to maximize rank-order correlation between distance in ordination space and dissimilarity between sites. Unlike other ordination techniques (e.g., principal components analysis), axis order does not represent the amount of variability explained, so ordinations can be rotated and inverted to better interpret data. Goodness-of-fit is determined by the stress of the ordination, which is inversely proportional to the rankorder correlation. We used Bray-Curtis distance to measure ecological dissimilarity because it is less sensitive to infrequently observed species and most sensitive to those that are abundant (Field et al., 1982). We combined all pasture-year combinations in a single data matrix, enabling us to compare ecological dissimilarity in both space and time.

\section{Results}

\section{Habitat Heterogeneity}

Spatial heterogeneity, measured as contrast among patches within a pasture, was greater in patch-burn graze pastures than in other treatments starting in 2008, although standard error bars overlapped through much of this timeframe (Fig. 2). Graze-and-burn sites showed moderate contrast, and burn-only sites displayed the lowest contrast overall. However, contrast in patch-burn graze pastures in 2010-2011 was similar to earlier years in terms of the magnitude of difference with other treatments. In 2012-2013 the magnitude of these differences increased markedly (see Fig. 2) lending support to our first hypothesis that reduced stocking rates would lead to increased heterogeneity on patch-burned pastures. Contrast spiked in 2012 in all treatments, possibly due to differences within pastures in vegetation response to drought that year. Our second measure of heterogeneity, standard deviation of litter cover, was generally greatest in patch-burn graze pastures relative to the other treatments. Although between-year variability was high, litter contrast for the patch-burn graze treatment was consistently higher than the other two treatments after 2009 (Fig. 3).

\section{Avian Community}

From 2010 to 2013, we recorded 8081 birds of 60 species, including 19 grassland species. Of these grassland species, 8 were grassland obligates (i.e., entirely grassland dependent) and 11 were facultative species (i.e., utilize habitats other than grasslands; Vickery et al., 1999) (Table 1). Among the most commonly observed species were dickcissels (Spiza americana; $19.0 \%$ of all observations), grasshopper sparrows (Ammodramus savannarum; 13.3\%), bobolinks (Dolichonyx oryzivorus; 10.9\%), and red-winged blackbirds (Agelaius phoeniceus; 10.6\%). Three obligate species (grasshopper sparrow, bobolink, and eastern meadowlark (Sturnella magna)), were most common on patch-burn graze pastures as compared with the other two treatments. Henslow's sparrows (Ammodramus henslowii) and sedge wrens (Cistothorus platensis), two species that prefer less disturbed habitat, reached their highest densities on burn-only pastures (Table 1). However, they reached moderate densities on patch-burned pastures and were more abundant there compared with graze-and-burn sites.

As in phase 1 of the project, overall species richness did not differ among treatments $\left(F_{2,42}=1.81, P=0.218\right)$ or years $\left(F_{3,42}=0.29, P=\right.$ $0.834)$, nor did we detect differences in overall species diversity among treatments $\left(F_{2,42}=1.43, P=0.29\right)$ or years $\left(F_{3,42}=0.41, P=0.745\right)$. The richness of grassland obligate species showed some differences among treatments $\left(F_{2,42}=2.53, P=0.092\right)$ and no difference among years $\left(F_{3,42}=1.51 P=0.227\right)$. However, Shannon diversity of grassland obligate species exhibited strong differences among treatments $\left(F_{2,42}=\right.$ $7.18, P=0.002)$ and among years $\left(F_{3,42}=2.83, P=0.05\right)$. On average, obligate diversity was greatest for patch-burn graze pastures and lowest for the burn-only treatment; this was especially apparent in 2012 and 2013. This result differs drastically from the first phase, when no differences in obligate diversity were found among treatments (Fig. 4). 


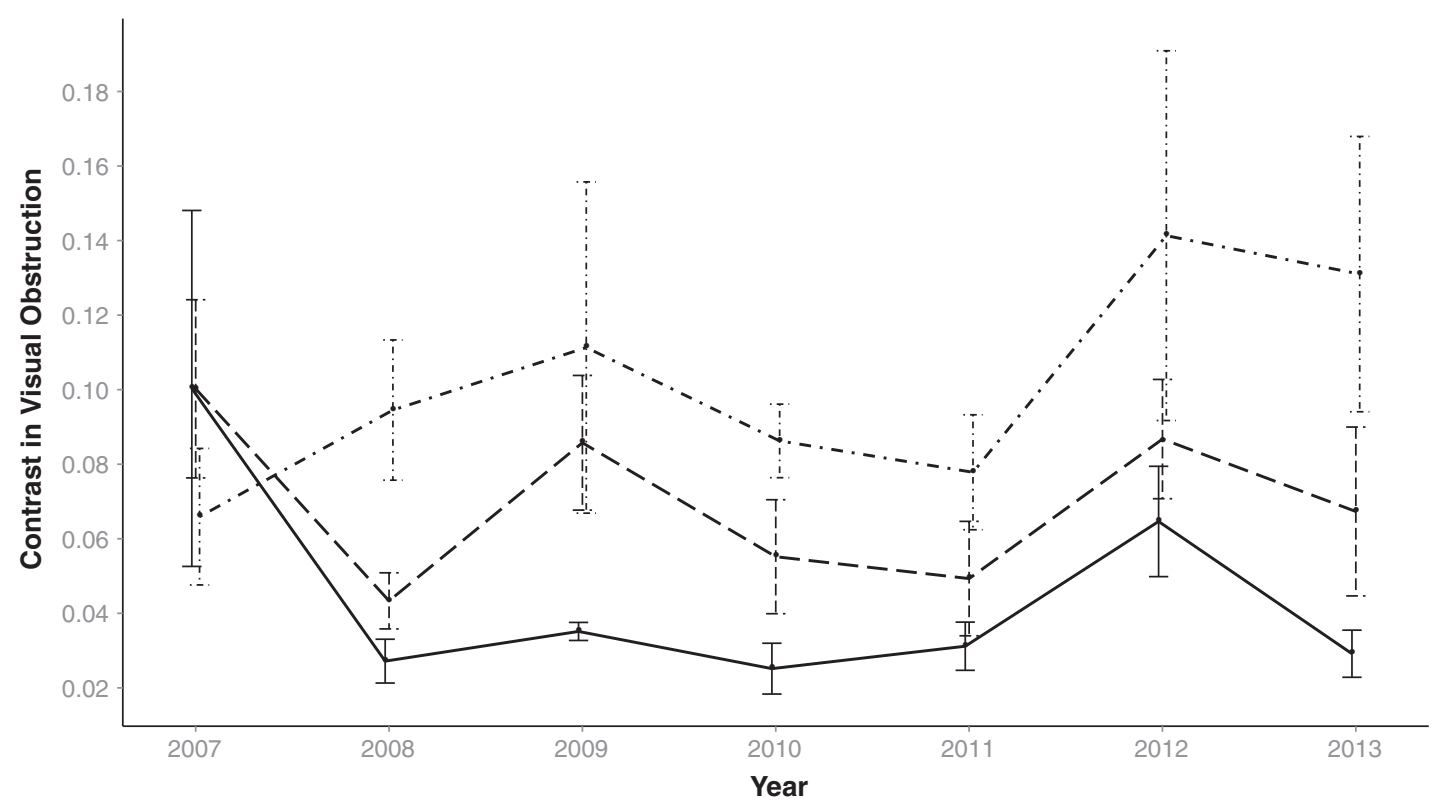

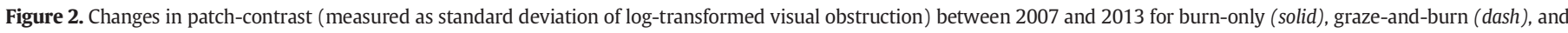
patch-burn graze (dot-dash) treatments. Bars represent standard errors.

Model comparisons also did not indicate an effect of treatment on overall Shannon diversity (Table 2). Because neither treatment nor landscape variables improved upon the null model, the final model included the combined effects of fescue $\left(\beta_{\text {Fesc }}=0.003\right.$; [85\% CI 0.001, $0.004]$ ) and pasture size ( $\beta_{\text {Past_size }}=0.00$; $[85 \% \mathrm{CI} 0.002,0.008]$ ). Other single-variable habitat models including cover of warm-season grasses ( $\beta_{\mathrm{WSG}}=-0.002 ;[85 \% \mathrm{CI}-0.004,-0.001]$ ) and litter $\left(\beta_{\mathrm{WSG}}=0.002 ;[85 \% \mathrm{CI} 0.001,0.004]\right)$ were only slightly better than the null model (i.e., within $<2 \mathrm{AIC}_{\mathrm{c}}$ ).

In contrast, model comparison indicated that treatment, pasture size, habitat, and landscape variables all influenced obligate species diversity (Table 3 ). The best overall model contained both treatment and percent grass cover within $1 \mathrm{~km}$, in addition to pasture size (Table 4). Results indicated that obligate diversity was highest on patch-burn graze pastures, and that diversity increased with increasing grass cover in the landscape and increasing pasture size. The best singlevariable model was treatment (see Table 3 ). Regarding within-pasture habitat features, models including patch-contrast of litter $\left(\beta_{\text {Litcon }}=\right.$ 0.388; [ $85 \% \mathrm{CI} 0.126,0.651)$, visual obstruction ( $\beta_{\mathrm{VO}}=-0.049 ;[85 \%$ $\mathrm{CI}-0.082,-0.015])$, and fescue cover $\left(\beta_{\mathrm{Fesc}}=0.004\right.$; [85\% CI 0.002, 0.007]) were all better than the null model (see Table 3), indicating that all three variables have the potential to increase obligate bird diversity. Among landscape variables, only grass cover within $1 \mathrm{~km}$ of study sites improved upon the null model.

Results from PerMANOVA showed that avian community structure differed among treatments $\left(F_{2,36}=4.890, P=0.001\right)$ and years $\left(F_{3,36}=2.699, P=0.001\right)$, supporting the previous tests and our second hypothesis. There was no evidence of an interaction between treatment

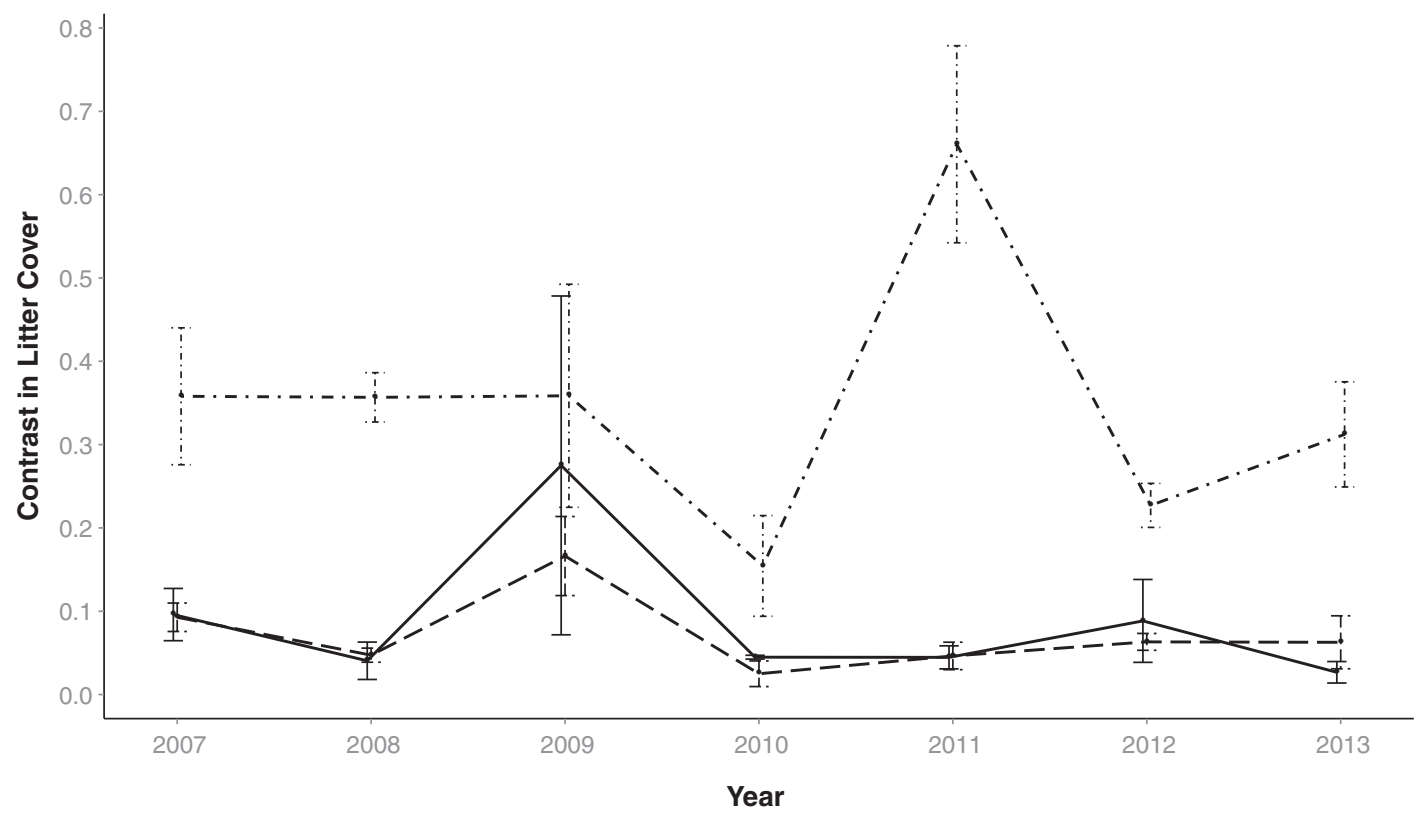

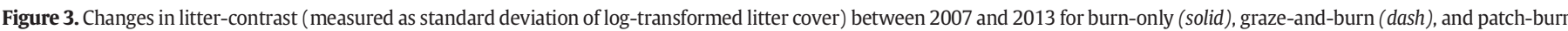
graze (dot-dash) treatments. Bars represent standard errors. 
Table 1

Raw average observed density (ha) by treatment of obligate and facultative grassland birds between 2010 and 2013 ( \pm SE).

\begin{tabular}{|c|c|c|c|c|}
\hline Species & All & Patch-burn graze & Graze-and-burn & Burn-only \\
\hline \multicolumn{5}{|l|}{ Obligate Grassland Species } \\
\hline$\overline{\text { Dickcissel (Spiza americana) }}$ & $1.087(0.092)$ & $1.048(0.132)$ & $0.941(0.141)$ & $1.271(0.195)$ \\
\hline Grasshopper sparrow (Ammodramus savannarum) & $0.865(0.077)$ & $1.21(0.07)$ & $1.004(0.132)$ & $0.379(0.093)$ \\
\hline Bobolink (Dolichonyx oryzivorus) & $0.81(0.076)$ & $0.936(0.102)$ & $0.722(0.15)$ & $0.771(0.142)$ \\
\hline Eastern meadowlark (Sturnella magna) & $0.587(0.06)$ & $0.909(0.102)$ & $0.661(0.062)$ & $0.189(0.043)$ \\
\hline Henslow's sparrow (Ammodramus henslowii) & $0.374(0.059)$ & $0.462(0.102)$ & $0.141(0.048)$ & $0.518(0.122)$ \\
\hline Sedge wren (Cistothorus platensis) & $0.208(0.048)$ & $0.139(0.054)$ & $0.091(0.036)$ & $0.395(0.117)$ \\
\hline Vesper sparrow (Pooecetes gramineus) & $0.007(0.004)$ & - & $0.021(0.012)$ & - \\
\hline Upland sandpiper (Bartramia longicauda) & $0.006(0.004)$ & $0.019(0.011)$ & - & - \\
\hline \multicolumn{5}{|l|}{ Facultative Grassland Species } \\
\hline$\overline{\text { Red-winged blackbird (Agelaius phoeniceus) }}$ & $0.751(0.078)$ & $0.625(0.127)$ & $0.775(0.117)$ & $0.854(0.161)$ \\
\hline Brown-headed cowbird (Molothrus ater) & $0.525(0.046)$ & $0.547(0.062)$ & $0.546(0.075)$ & $0.482(0.102)$ \\
\hline Eastern kingbird (Tyrannus tyrannus) & $0.335(0.031)$ & $0.309(0.05)$ & $0.367(0.052)$ & $0.329(0.064)$ \\
\hline Common yellowthroat (Geothlypis trichas) & $0.319(0.041)$ & $0.176(0.043)$ & $0.256(0.066)$ & $0.525(0.071)$ \\
\hline Mourning dove (Zenaida macroura) & $0.086(0.03)$ & $0.044(0.023)$ & $0.073(0.022)$ & $0.141(0.083)$ \\
\hline Northern bobwhite (Colinus virginianus) & $0.041(0.019)$ & $0.038(0.027)$ & $0.073(0.049)$ & $0.01(0.01)$ \\
\hline Eastern bluebird (Siala sialis) & $0.035(0.011)$ & $0.028(0.016)$ & $0.045(0.018)$ & $0.031(0.024)$ \\
\hline Loggerhead shrike (Lanius ludovicianus) & $0.029(0.011)$ & - & $0.079(0.028)$ & $0.008(0.008)$ \\
\hline Ring-necked pheasant (Phasianus colchicus) & $0.008(0.005)$ & - & - & $0.023(0.013)$ \\
\hline Killdeer (Charadrius vociferous) & $0.006(0.004)$ & $0.013(0.013)$ & - & $0.005(0.005)$ \\
\hline Lark sparrow (Chondestes grammacus) & $0.003(0.003)$ & - & - & $0.008(0.008)$ \\
\hline
\end{tabular}

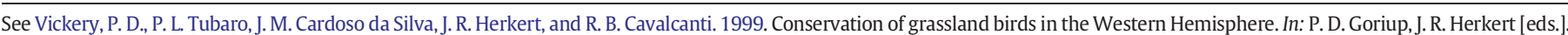
Ecology and conservation of grassland birds of the Western Hemisphere. Studies in avian biology. Los Angeles, CA, USA: Cooper Ornithological Society. p. 2-26.

and year $\left(F_{6,36}=0.73, P=0.883\right)$. We used PCOrd (McCune and Mefford, 2011) to examine differences between individual treatments. Uncorrected pair-wise tests indicated the greatest differences in species distribution and abundance between burn-only and graze-and-burn pastures $(t=2.354, P=0.001)$ and burn-only and patch-burn graze pastures $(t=2.782, P=0.001)$. These tests also indicated substantial differences between the two grazing treatments $(t=1.536, P=0.039)$.

NMDS achieved a three-dimensional solution with a stress of $15.36 \%$, which is considered a fair fit to the data (Kruskal, 1964). The three axes had $r^{2}$ values of $0.306,0.306$, and 0.244 ; to ease interpretation of figures, the two axes with the highest $r^{2}$ values are presented (Fig. 5). Bird communities in burn-only pastures were the most variable of the three treatments over space and time, illustrated by the large distance between ordination points. Graze-and-burn pastures were intermediate in this regard, whereas bird communities in patch-burn graze pastures showed the least variability. This pattern in combination with the temporally consistent central location of patch-burn graze pastures in ordination space suggests greater community stability over time relative to the other two treatments.

\section{Discussion}

Our results indicate that the level of habitat heterogeneity necessary for a more diverse grassland bird community can be achieved using patch-burn grazing, even on small patches in highly fragmented working landscapes. Within-pasture (i.e., visual obstruction) and landscape (i.e., grassland within $1 \mathrm{~km}$ ) metrics influenced avian diversity, and larger pastures generally had more diverse communities, but treatment was by far the best single variable explaining differences in obligate grassland bird diversity on our experimental pastures. Avian diversity was greatest in patch-burn graze pastures, particularly in the latter years of our study.

The increase in diversity over time on patch-burn graze pastures was linked with increased structural heterogeneity, providing support for our first hypothesis that lowering stocking rate increases habitat heterogeneity in patch-burned pastures. Habitat heterogeneity, in turn, was linked to increased avian diversity, supporting our second hypothesis. Though it has long been understood that heavy stocking rates can negatively influence indicators of grassland quality (Briske et al.,

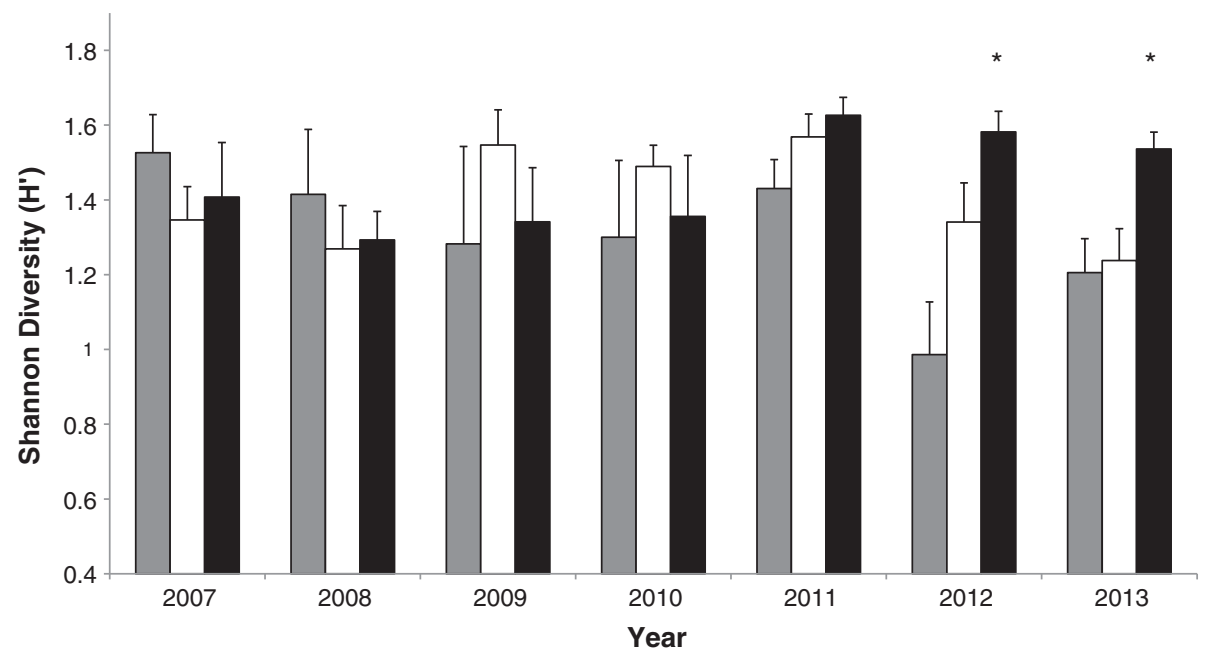

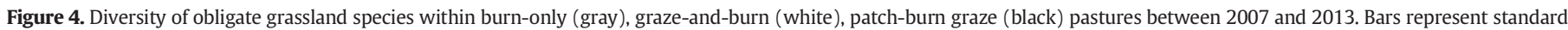
errors. Asterisks indicate significant differences among treatments at $\alpha=0.05$. 
Table 2

Generalized linear models explaining the effects of treatment and habitat and landscape features on overall grassland bird diversity. Only single-variable and final combined models better than the null are shown. Table includes the number of parameters included in the model $(K)$, Akaike's information criterion adjusted for small sample sizes $\left(\mathrm{AIC}_{\mathrm{c}}\right)$, $\Delta \mathrm{AIC}_{\mathrm{C}}$, and model weights $\left(w_{i}\right)$. Superscripts indicate the top habitat and landscape models.

\begin{tabular}{lllll}
\hline Model & $\mathrm{K}$ & AICc & $\Delta$ AICc & $w_{i}$ \\
\hline${\text { Pasture size }+ \text { fescue }^{1}}_{\text {Fescue }^{2}}$ & 3 & -54.1 & 0 & 0.62 \\
Pasture size $_{\text {Litter }}$ & 2 & -51.9 & 2.1 & 0.21 \\
Warm-season grass & 2 & -48.4 & 5.7 & 0.04 \\
Null & 2 & -47.8 & 6.2 & 0.03 \\
\hline
\end{tabular}

1 Indicates final best model incorporating the effects of habitat and pasture size.

2 Indicates habitat model with highest model weight.

2011), the relationship between stocking rate and the fire-grazing interaction has only recently been examined. Scasta (2014) examined a number of variables that may potentially inhibit management efficacy in this system (e.g., burn completeness, canopy cover of the dominant invasive plant species) and concluded that stocking rate was by far the most important factor in achieving adequate patch contrast on patchburned pastures. Both overstocking from 2007 to 2009 and understocking from 2010 to 2011 served to homogenize patch-burned pastures in these years. Through adjusting stocking rate, we observed patch-contrast on research pastures in recent years (2012-2013) that is comparable with those achieved in studies of the fire-grazing interaction conducted on larger grasslands (McGranahan et al., 2012b). Thus, although our initial hypothesis was that reduction in stocking rate would increase heterogeneity, simply reducing to a low stocking rate in 2010 and 2011 was not sufficient to achieve patch contrast. It was not until we achieved relatively moderate rates, adjusted each year on the basis of residual vegetation in study pastures, that we observed desired levels of patch contrast. In these same years, obligate grassland bird diversity peaked, a result that differs markedly from patterns

\section{Table 3}

Generalized linear models explaining the effects of treatment and habitat and landscape features on the diversity of grassland obligate species. Only single-variable and final combined models better than the null are shown. For each model, column headings include K, the number of parameters included in the model; $\mathrm{AIC}_{\mathrm{c}}$, Akaike's information criterion adjusted for small sample sizes; $\Delta \mathrm{AIC}_{c}$; and $w_{i}$, model weights. Superscripts indicate the top habitat and landscape models, as well as the top overall model.

\begin{tabular}{|c|c|c|c|c|}
\hline Model & K & $\mathrm{AIC}_{\mathrm{c}}$ & $\Delta \mathrm{AIC}_{\mathrm{c}}$ & $w_{i}$ \\
\hline Treatment + Grass_1 km + Pasture size ${ }^{1}$ & 5 & -3.2 & 0 & 0.34 \\
\hline Grass_1 km + Fescue + Pasture size & 4 & -2.7 & 0.5 & 0.26 \\
\hline Treatment + Grass_1 km + Fescue + Pasture size & 6 & -1.9 & 1.3 & 0.18 \\
\hline Treatment + Grass_1km & 4 & -0.6 & 2.6 & 0.09 \\
\hline Treatment + Pasture size & 4 & 1.0 & 4.2 & 0.04 \\
\hline Treatment + Grass_1km + Fescue & 5 & 1.6 & 4.8 & 0.03 \\
\hline Treatment $^{2}$ & 3 & 2.9 & 6.1 & 0.02 \\
\hline Treatment + Fescue + Pasture size & 5 & 2.9 & 6.1 & 0.02 \\
\hline Pasture Size + Fescue & 3 & 3.1 & 6.3 & 0.01 \\
\hline Fescue + Grass_1 km & 3 & 3.1 & 6.3 & 0.01 \\
\hline Pasture size + Grass_1 km & 3 & 3.2 & 6.4 & 0.01 \\
\hline Treatment + Fescue & 4 & 3.7 & 6.9 & 0.01 \\
\hline Pasture size & 2 & 6.3 & 9.5 & 0.00 \\
\hline Fescue $^{3}$ & 2 & 7.6 & 10.8 & 0.00 \\
\hline Litter contrast & 2 & 8.2 & 11.4 & 0.00 \\
\hline Visual obstruction $^{4}$ & 2 & 8.4 & 11.6 & 0.00 \\
\hline Grass_1 $1 \mathrm{~km}^{5}$ & 2 & 8.4 & 11.6 & 0.00 \\
\hline Null & 1 & 10.2 & 13.4 & 0.00 \\
\hline
\end{tabular}

1 Indicates final best model incorporating treatment, as well as top models of habitat, landscape, and pasture size.

2 Indicates the best single-variable model (i.e., highest model weight among singlevariable models).

${ }^{3}$ Indicates habitat model with the highest model weight.

4 Metric incorporating both vegetation height and density (Robel 1970).

${ }^{5}$ Indicates landscape model with highest model weight.
Table 4

Coefficients from top model of diversity of grassland obligate species, as well as $85 \%$ confidence intervals $(\mathrm{CI}){ }^{1}$

\begin{tabular}{|c|c|c|c|}
\hline Variable & $\beta$ & $85 \% \mathrm{CI}$ & \\
\hline Pasture area & 0.009 & 0.003 & 0.014 \\
\hline \multicolumn{4}{|l|}{ Treatment } \\
\hline Burn-only & -0.258 & -0.363 & -0.153 \\
\hline Graze-and-burn & -0.080 & -0.186 & 0.027 \\
\hline Patch-burn graze & 0.785 & 0.469 & 1.101 \\
\hline \multicolumn{4}{|l|}{ Landscape } \\
\hline Grass_1km & 0.008 & 0.004 & 0.013 \\
\hline
\end{tabular}

1 85\% confidence limits. From Arnold, T.W. 2010. Uninformative parameters and mode selection using Akaike's Information Criterion. Journal of Wildlife Management 74:1175-1178.

observed early in the project, when diversity did not differ among treatments (Pillsbury et al., 2011).

Our second hypothesis, that pasture-scale heterogeneity would be the primary driver of local avian diversity, was partially supported in that heterogeneity was a major driver of the diversity of grassland obligate birds. Unlike facultative species, which will use other habitat types (e.g., red-winged blackbirds in wetlands, mourning doves [Zenaida macroura] in woodlands), obligate grassland birds rely almost exclusively on grassland and herbaceous habitats. Although some obligates will use a wider variety of herbaceous substrates (e.g., bobolinks in alfalfa and hayfields; Ribic et al., 2009a), other species are generally constrained to remnant or restored prairie (e.g., grasshopper sparrow, Henslow's sparrow). It is therefore unsurprising that species relying more heavily on grassland habitats (i.e., obligates) would show a stronger response to management than species using other habitats. Also unlike facultative species, many of which have stable or increasing populations (e.g., brown-headed cowbird), all of the obligate grassland birds observed in this study are in decline throughout much of their ranges. Patch-burn grazing is therefore especially useful in this context, in that it is a management technique that specifically benefits declining species.

Heterogeneity was not the only driver of diversity. Larger pastures had consistently higher obligate diversity, which is not surprising. Many other studies of grassland birds have highlighted the positive effects of patch size on density (Davis, 2004; Winter et al., 2006; Ribic et al., 2009b), diversity (Helzer and Jelinski, 1999), and breeding success (Ribic et al., 2009b). However, in our study the effect of treatment on obligate diversity was much stronger than pasture size, indicating that patch-burn grazing can at least partially override patch size limitations on diversity.

Within-pasture factors also influenced avian response to the firegrazing interaction. Reviewing the modeling results, we did not anticipate the influence of visual obstruction and tall fescue cover on avian diversity. Although we expected variation in visual obstruction (i.e., patch contrast) to be a key driver, we found that areas with shorter vegetation had more diverse communities of obligate species. This is likely a function of several species that are scarce or absent in very dense, unburned pastures (i.e., grasshopper sparrow, eastern meadowlark), whereas species like Henslow's sparrows and bobolinks can still occur in moderately dense vegetation on patch-burned pastures. The positive relationship between bird diversity and tall fescue cover is less easily explained, because invasion by tall fescue has been linked to negative impacts on grassland birds (Barnes et al., 1995; Hovick et al., 2011). However, parameter estimates generated from the final model indicate that the importance of tall fescue is likely small or unimportant relative to other factors, as the $\mathrm{AIC}_{\mathrm{c}}$ value for the single-variable fescue model was $<3$ $\triangle \mathrm{AICc}$ better than the null model.

Echoing previous studies of grassland birds (Cerezo et al., 2011; Davis et al., 2013; Lipsey et al., 2015), the amount of grassland within a kilometer of our study pastures was strongly associated with higher levels of diversity of grassland obligate birds. Our third hypothesis was therefore partially supported, as we did not observe a concurrent influence of land cover on overall bird diversity. As discussed 


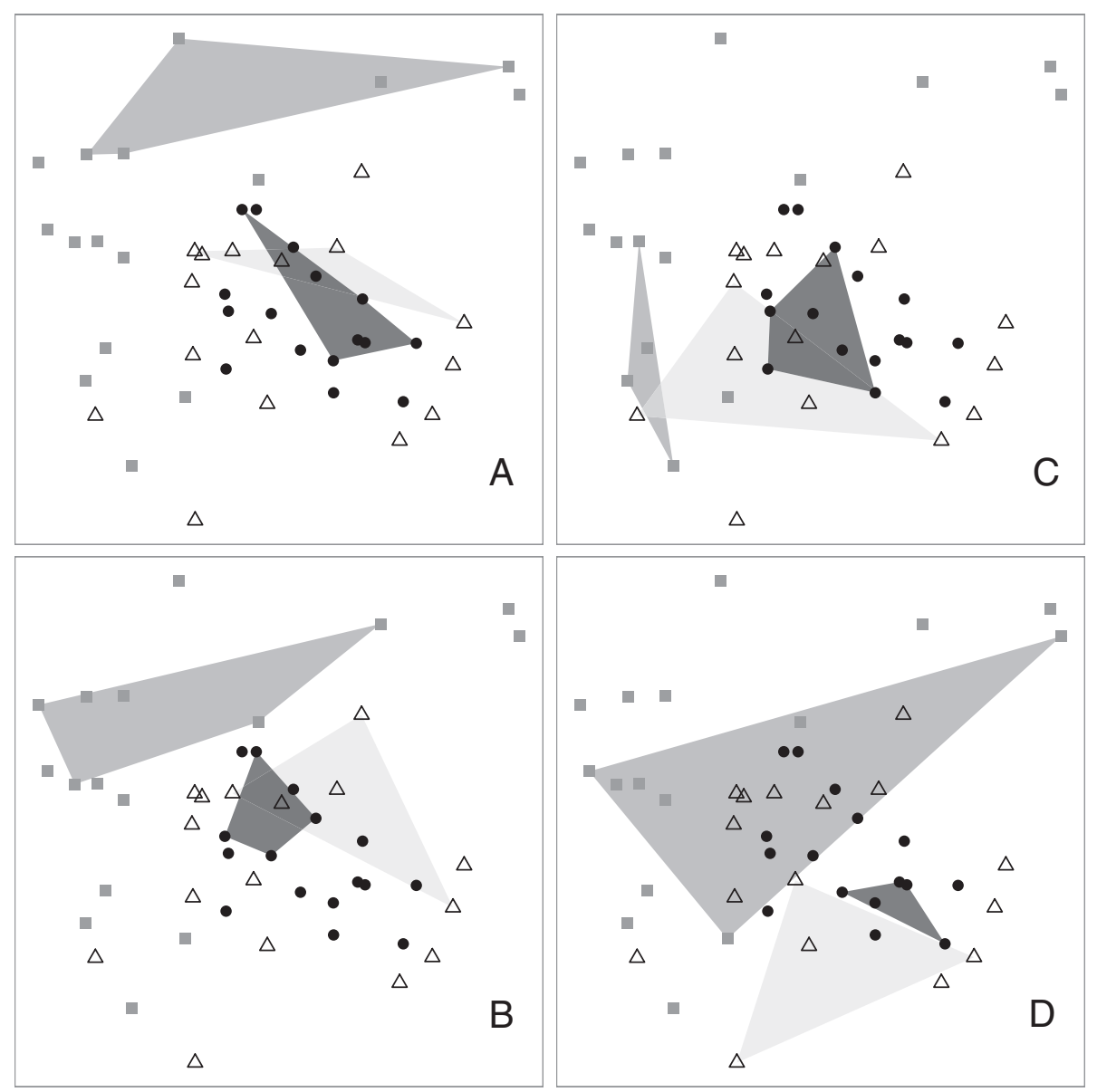

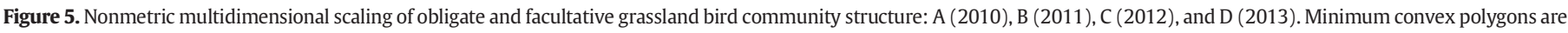

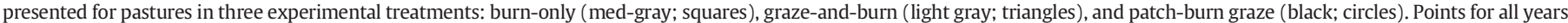
are included in each panel, but only points from a given year are included in polygons.

previously, this is likely because of a comparatively greater dependence of obligate species on grassland habitat as compared with facultative species, leading to a stronger connection between these species and grassland habitat in the landscape. Surprisingly, we did not observe reduced diversity in response to increased forest cover or cropland cover, as has been observed in some studies (Bakker et al., 2002; Thompson et al., 2014). Nonetheless, our results reflect a key tenet of landscape ecology: the influence of the matrix increases as patch size decreases (Turner, 1989). Thus, land use and land cover in working landscapes may serve as a key control on the effect of habitat heterogeneity in grassland remnants.

In general, avian community structure differed among treatments, and although ordinations indicated a slight overlap among treatments, bird communities within treatments became more differentiated over time. Most notably, both grazed treatments tended to have more similar communities than pastures that were not grazed. This trend was consistent over the first and second phases of the project, as ordinations of the 2006-2009 data showed high differentiation of burn-only polygons and overlap of the grazed treatments (Pillsbury et al., 2011). This is likely because ungrazed pastures did not provide habitat for species preferring lower vegetation (e.g., grasshopper sparrows). Even in years when ungrazed pastures were burned, without grazing to impede regrowth after fire, vegetation was too tall and dense by the start of breeding season to provide habitat for these species.

Another notable pattern in the ordinations was the high level of community stability in patch-burn graze pastures, as depicted by the relatively static position of the patch-burn graze polygon in ordination space across time. Conversely, pastures in the other treatments were more variable in ordination space, indicating a greater degree of temporal fluctuation in community structure. The relatively constant availability of patches in different stages of disturbance in patch-burn graze pastures may serve to buffer against temporal variability (Benton et al., 2003)-variability imposed by factors such as change in haying practices and conversion of grassland to row crop.

This stability may also be a buffer for climatic extremes, such as drought. Much of the United States experienced an extreme drought in 2012, which had negative impacts on both agriculture and wildlife. Effective precipitation on our sites that year was only $448 \mathrm{~mm}$, by far the lowest of the study (Iowa Environmental Mesonet, 2014). The combination of drought, fire, and grazing meant graze-and-burn pastures had very little residual vegetation in 2012, and many had scant litter cover in 2013. We also observed a marked decrease in obligate bird diversity in graze-and-burn and burn-only pastures in these years (see Fig. 4). However, diversity on patch-burn graze pastures remained fairly stable between 2011 and 2013. Because fire was only applied to one patch on patch-burn graze pastures and selective grazing pressure was higher on that patch, unburned and less preferentially grazed patches within the same pasture likely provided habitat that was less available on the other two treatments during this period of drought. This "buffer" effect is also important for livestock and may be a means of maintaining agricultural productivity in times of drought (Allred et al., 2014). Considering predictions of an increasingly variable climate (Wuebbles and Hayhoe, 2004; ICCIC, 2010), the sustained availability of patches of differing structure (i.e., in different stages of disturbance) provided by patch-burn grazing may confer even greater value to this management framework in the future. 


\section{Management Implications}

Results of our study highlight the fact that mimicking historic disturbance regimes, although an appealing goal, is not always straightforward in practice. Simply applying patchy fires and introducing cattle grazing was insufficient to create the level of habitat heterogeneity we anticipated on our experimental pastures. Though selecting the appropriate stocking rate is important in all grazed systems, there may be a smaller margin of error for stocking rate when implementing the firegrazing interaction to restore habitat heterogeneity in small grassland pastures, in contrast to large pastures in many rangeland regions where heterogeneity exists naturally because of variable terrain and ecological sites (Fuhlendorf and Engle, 2001). Because most remaining grasslands in the Midwest are small and fragmented, our results are especially germane to managers in this region, but these findings are applicable to small grassland patches throughout North America. In identifying the importance of stocking rate to patch-burn grazing, we have taken an important step in understanding how best to manage for imperiled birds on small grassland patches.

\section{Acknowledgements}

The authors acknowledge the support of the Oklahoma Agricultural Experiment Station and the Iowa Agricultural and Home Economics Experiment Station. S. Rusk, T. Lyons, and A. Meyer assisted in the collection of bird data. Thanks also to R. Harr, S. Rusk, and J. Rusk for logistical assistance, as well as to the students and technicians who worked on different stages of this long-term project, including D. McGranahan, F. Pillsbury, J. Delaney, J. D. Scasta, R. Moranz, S. Nelson, A. Keigher, C. Krassa, and M. Kneitel. We also thank J. Hennig, S. Davis, and 2 anonymous reviewers for comments that greatly improved this manuscript.

\section{Appendix 1. Model sets used for AIC $_{c}$ model comparison for overall and obligate diversity. AIC $_{c}$ values were generated for each single- variable model, and the best single-variable model from each set was included in a final model set. If no model in a given model group was better than the null, it was not included in the final model set. The final model set included all two-, three-, and four-way possible combinations of the "best" variables}

\begin{tabular}{|c|c|c|c|}
\hline $\begin{array}{l}\text { Model Group 1: } \\
\text { Treatment }\end{array}$ & $\begin{array}{l}\text { Model Group 2: } \\
\text { Local Habitat }\end{array}$ & $\begin{array}{l}\text { Model Group 3: } \\
\text { Landscape }\end{array}$ & $\begin{array}{l}\text { Model Group 4: } \\
\text { "Nuisance" }\end{array}$ \\
\hline $\begin{array}{l}\text { Treatment } \\
\text { Null }\end{array}$ & $\begin{array}{l}\text { Visual obstruction } \\
\text { Litter } \\
\text { Visual obstruction } \\
\text { contrast } \\
\text { Litter contrast } \\
\text { Warm-season grass } \\
\text { Fescue } \\
\text { Forb } \\
\text { Legume } \\
\text { Null }\end{array}$ & $\begin{array}{l}\text { Tree_300m } \\
\text { Grass_300m } \\
\text { Crop_300m } \\
\text { Tree_1km } \\
\text { Grass_1km } \\
\text { Crop_1km } \\
\text { Null }\end{array}$ & $\begin{array}{l}\text { Year } \\
\text { Pasture size } \\
\text { Null }\end{array}$ \\
\hline
\end{tabular}

\section{References}

Allouche, O., Kalyuzhny, M., Moreno-Rueda, G., Pizarro, M., Kadmon, R., 2012. Areaheterogeneity tradeoff and the diversity of ecological communities. Proc. Natl. Acad. Sci. 109, 17495-17500.

Allred, B.W., Scasta, J.D., Hovick, T.J., Fuhlendorf, S.D., Hamilton, R.G., 2014. Spatial heterogeneity stabilizes livestock productivity in a changing climate. Agric. Ecosyst. Environ. 193, 37-41.

Anderson, D.R., 2008. Model based inference in the life sciences: a primer on evidence. Springer, New York, NY, USA (184 pp.)

Anderson, M.J., 2001. A new method for non-parametric multivariate analysis of variance. Austral Ecol 26, 32-46.

Anderson, R.C., 2006. Evolution and origin of the central grassland of North America: climate, fire, and mammalian grazers. Journal Torrey Botanical Society 133, 626-647.
Arnold, T.W., 2010. Uninformative parameters and model selection using Akaike's Information Criterion. J. Wildl. Manag. 74, 1175-1178.

Askins, R.A., Chavez-Ramirez, F., Dale, B.C., Hass, C.A., Herkert, J.R., Knopf, F.L., Vickery, P.D. 2007. Conservation of grassland birds in North America: understanding ecological processes in different regions. Ornithol. Monogr. 64, 1-46.

Bakker, K.K., Naugle, D.E., Higgins, K.F., 2002. Incorporating landscape attributes into models for migratory grassland bird conservation. Conserv. Biol. 16, 1638-1646.

Bar-Massada, A., Wood, E.M., 2014. The richness-heterogeneity relationship differs between heterogeneity measures within and among habitats. Ecography 37, 528-535.

Barnes, T.G., Madison, L.A., Sole, J.D., Lacki, M.J., 1995. An assessment of habitat quality for Northern bobwhite in tall fescue-dominated fields. Wildl. Soc. Bull. 23, 231-237.

Benton, T.G., Vickery, J.A., Wilson, J.D., 2003. Farmland biodiversity: is habitat heterogeneity the key? Trends Ecol. Evol. 18, 182-188.

Best, L.B., Freemark, K.E., Dinsmore, J.J., Camp, M., 1995. A review and synthesis of habitat use by breeding birds in agricultural landscapes of Iowa. Am. Midl. Nat. 134, 1-29.

Best, L.B., Campa, H., Kemp, K.E., Robel, R.J., Ryan, M.R., Savidge, J.A., Weeks Jr., H.P., Winterstein, S.R., 1997. Bird abundance and nesting in CRP fields and cropland in the Midwest: a regional approach. Wildl. Soc. Bull. 25, 864-877.

Bollinger, E.K., Gavin, T.A., 2004. Responses of nesting bobolinks (Dolichonyx oryzivorus) to habitat edges. Auk 121, 767-776.

Brawn, J.D., Robinson, S.K., Thompson III, F.R., 2001. The role of disturbance in the ecology and conservation of birds. Annu. Rev. Ecol. Evol. Syst. 32, 251-276.

Brennan, L.A., Kuvlesky, I.P., 2005. North American grassland birds: an unfolding conservation crisis? J. Wildl. Manag. 69, 1-13.

Briske, D.D., Derner, J.D., Milchunas, D.G., Tate, K.W., 2011. An evidence-based assessment of prescribed grazing practices. In: Briske, D.D. (Ed.), Conservation benefits of rangeland practices: assessment, recommendations, and knowledge gaps. USDA-NRCS, Washington, DC, USA, pp. 21-74.

Cerezo, A., Conde, M.C., Poggio, S.L., 2011. Pasture area and landscape heterogeneity are key determinants of bird diversity in intensively managed farmland. Biodivers. Conserv. 20, 2649-2667.

Coppedge, B.R., Fuhlendorf, S.D., Harrell, W.C., Engle, D.M., 2008. Avian community response to vegetation and structural features in grasslands managed with fire and grazing. Biol. Conserv. 141, 1196-1203.

Cunningham, M.A., Johnson, D.H., 2006. Proximate and landscape factors influence grassland bird distributions. Ecol. Appl. 16, 1062-1075.

Daubenmire, R., 1959. Measurement of species diversity using canopy coverage classes. Northwest Science 33, 43-66.

Davis, S.K., 2004. Area sensitivity in grassland passerines: effects of patch size, patch shape, and vegetation structure on bird abundance and occurrence in southern Saskatchewan. Auk 121, 1130-1145.

Davis, S.K., Fisher, R.J., Skinner, S.L., Shaffer, T.L., Brigham, R.M., 2013. Songbird abundance in native and planted grassland varies with type and amount of grassland in the surrounding landscape. J. Wildl. Manag. 77, 908-919.

Engle, D.M., Coppedge, B.R., Fuhlendorf, S.D., 2008a. From the dust bowl to the green glacier: Human activity and environmental change in Great Plains grasslands. In: Auken, O.W. (Ed.), Western North American juniperus communities. Springer, New York, NY, USA, pp. 253-271.

Engle, D.M., Fuhlendorf, S.D., Roper, A., Leslie Jr., D.M., 2008b. Invertebrate community response to a shifting mosaic of habitat. Rangel. Ecol. Manag. 61, 55-62.

Field, J.G., Clarke, K.R., Warwick, R.M., 1982. A practical strategy for analyzing multispecies distribution patterns. Marine Ecology-Progress Series 8, 37-52.

Fisher, R.J., Davis, S.K., 2010. From Wiens to Robel: a review of grassland-bird habitat selection. J. Wildl. Manag. 74, 265-273.

Fraterrigo, J.M., Rusak, J.A., 2008. Disturbance-driven changes in the variability of ecological patterns and processes. Ecol. Lett. 11, 756-770.

Fuhlendorf, S.D., Engle, D.M., 2001. Restoring heterogeneity on rangelands: ecosystem management based on evolutionary grazing patterns. Bioscience 51, 625-632.

Fuhlendorf, S.D., Engle, D.M., 2004. Application of the fire-grazing interaction to restore a shifting mosaic on tallgrass prairie. J. Appl. Ecol. 41, 604-614.

Fuhlendorf, S.D. Harrell, W.C., Engle, D.M., Hamilton, R.G., Davis, C.A., Leslie Jr., D.M., 2006 Should heterogeneity be the basis for conservation? Grassland bird response to fire and grazing. Ecol. Appl. 16, 1706-1716.

Fuhlendorf, S.D., Engle, D.M., Kerby, J., Hamilton, R., 2009. Pyric herbivory: rewilding landscapes through the recoupling of fire and grazing. Conserv. Biol. 23, 588-598.

Fuhlendorf, S.D., Townsend II, D.E., Elmore, R.D., Engle, D.M., 2010. Pyric-herbivory to promote rangeland heterogeneity: evidence from small mammal communities. Rangel. Ecol. Manag. 63, 670-678.

Fuhlendorf, S.D., Engle, D.M., Elmore, R.D., Limb, R.F., Bidwell, T.G., 2012. Conservation of pattern and process: developing an alternative paradigm of rangeland management Rangel. Ecol. Manag. 65, 579-589.

Helzer, C.J., Jelinski, D.E., 1999. The relative importance of patch area and perimeter-area ratio to grassland breeding birds. Ecological App1ications 94, 1448-1458.

Herkert, J.R., 1994. The effects of habitat fragmentation on midwestern grassland bird communities. Ecol. Appl. 4, 461-471.

Holechek, R.J., Pieper, R.D., Herbel, C.H., 2010. Range management: principles and practices. sixth ed. Prentice Hall, Upper Saddle River, NJ, USA (456 pp.).

Hovick, T.J., Miller, J.R., Koford, R.R., Engle, D.M., Debinski, D.M., 2011. Postfledging survival of grasshopper sparrows in grasslands managed with fire and grazing. Condor 113 429-437.

Hutto, R.L., 1985. Habitat selection by nonbreeding, migratory land birds. In: Cody, M.L (Ed.), Habitat selection in birds. Academic Press, Waltham, MA, USA, pp. 455-476.

ICCIC [Iowa Climate Change Impacts Committee], 2010. Climate change impacts on Iowa: re-port to the Governor and Iowa General Assembly. (Available at:) http:// iowaeconomicdevelopment.com/Programs/Energy (Accessed June 30 2015).

Iowa Environmental Mesonet, 2014. IEM climodat for Mt. Ayr. Iowa Mesonet Station. 
Knopf, F.L., 1994. Avian assemblages on altered grasslands. In: Jehl Jr., J.R., Johnson, N.K. (Eds.), A century of avifaunal change in western North AmericaStud. Avian Biol. 15, 247-257.

Knopf, F.L., 1996. Prairie legacies-birds. In: Knopf, F.B., Sampson, F.L. (Eds.), Prairie conservation: preserving North America's most endangered ecosystem. Island Press, Washington, DC, USA, pp. 135-148.

Kruskal, J.B., 1964. Nonmetric multidimensional-scaling: a numerical-method. Psychometrika 29, 115-129.

Lipsey, M.K., Doherty, K.E., Naugle, D.E., Fields, S., Evans, J.S., Davis, S.K., Koper, N., 2015 One step ahead of the plow: using cropland conversion risk to guide Sprague's Pipit conservation in the northern Great Plains. Biology Conservation 191739-191749.

Lyons, T.P., 2013. Nest predation and habitat selection in the grasshopper sparrow (Ammodramus savannarum) [MS thesis]. The University of Illinois, Urbana, IL, USA

Lyons, T.P., Miller, J.R., Debinski, D.M., Engle, D.M., 2015. Predator identity influences the effect of habitat management on nest predation. Ecology Applications 25, 1596-1605.

McArdle, B.H., Gaston, K.J., Lawton, J.H., 1990. Variation in the size of animal populations: patterns, problems and artifacts. J. Anim. Ecol. 59, 439-454.

McCune, B., Mefford, M.J., 2011. PC-ORD. Multivariate Analysis of Ecological Data.Version 6. MjM Software, Gleneden Beach, OR, USA.

McGranahan, D.A., Engle, D.M., Fuhlendorf, S.D., Miller, J.R., Debinski, D.M., 2012a. An invasive cool-season grass complicates prescribed fire management in a native warmseason grassland. Natural Areas Journal 32, 208-214.

McGranahan, D.A., Engle, D.M., Fuhlendorf, S.D., Winter, S.J., Miller, J.R., Debinski, D.M. 2012b. Statial heterogeneity across five rangelands managed with pyric-herbivory. J. Appl. Ecol. 49, 903-910.

McGranahan, D.A., Engle, D.M., Fuhlendorf, S.D., Miller, J.R., Debinski, D.M., 2013. Multivariate analysis of rangeland vegetation and soil organic carbon describes degradation, informs restoration and conservation. Land 2, 328-350.

Miller, J.R., Morton, L.W., Engle, D.M., Debinski, D.M., Harr, R.N., 2012. Nature reserves as catalysts for landscape change. Front. Ecol. Environ. 10, 144-152.

Oksanen, J., Blanchet, F.G., Kindt, R., Legendre, P., Minchin, P.R., O'Hara, R.B., Simpson, G.L., Solymos, P., Stevens, M.H.H., Wagner, H., 2011. Vegan: community ecology packagee. $\mathrm{R}$ package version $2.0-0$ (computer program).

Pillsbury, F. C., J. R. Miller, D. M. Debinski, D. M. Engle. 2011. Another tool in the toolbox? Using fire and grazing to promote bird diversity in highly fragmented landscapes. Ecosphere 2:art. 28

Powell, A.F.L.A., 2006. Effects of prescribed burns and bison (Bos bison) grazing on breeding bird abundances in tallgrass prairie. Auk 123, 183-197.

Ralph, C.J., Martin, T.E., Geupel, G.R., DeSante, D.F., Pyle, P., 1993. Handbook of field methods for monitoring landbirds. PSW-GTR-144. USDA, Forest Service, Pacific Southwest Research Station, Albany, CA, USA.

Renfrew, R.B., Ribic, C.A., Nack, J.L., 2005. Edge avoidance by nesting grassland birds: a futile strategy in a fragmented landscape. Auk 122, 618-636.

Ribic, C.A., Guzy, M.J., Sample, D.W., 2009a. Grassland bird use of remnant prairie and Conservation Reserve Program fields in an agricultural landscape in Wisconsin. Am. Midl. Nat. 161, 110-122.
Ribic, C.A., Koford, R.R., Herkert, J.R., Johnson, D.H., Niemuth, N.D., Naugle, D.E., Bakker, K.K., Sample, D.W., Renfrew, R.B., 2009b. Area sensitivity in North American grassland birds: patterns and processes. Auk 126, 233-244.

Ries, L., Fletcher, R.J., Battin, J., Sisk, J.D., 2004. Ecological responses to habitat edges: mechanisms, models, and variability explained. Annual Review of Ecology Evolution System 35, 491-522.

Robel, R.I., Briggs, J.N., Dayton, A.D., Hulbert, L.C., 1970. Relationships between visual obstruction measurements and weight of grassland vegetation. Journal of Rangeland Management 23, 295-297.

Samson, F., Knopf, F., 1994. Prairie conservation in North-America. Bioscience 44, 418-421.

Sauer, J.R., Hines, J.E., Fallon, J., 2011. The North American breeding bird survey, results and analysis 1966-2010. USGS Patuxent Wildlife Research Center, Laurel, MD, USA (Version 5.15.2008).

Scasta, J.D., 2014. Implications of pyric-herbivory on Central North American grassland ecology, management and production [Ph.D. dissertation]. Oklahoma State University, Stillwater, OK, USA.

Stein, A., Gerstner, K., Kreft, H., 2014. Environmental heterogeneity as a universal driver of species richness across taxa, biomes and spatial scales. Ecol. Lett. 17, 866-880.

Swengel, S.R., Swengel, A.B., 2001. Relative effects of litter and management on grassland bird abundance in Missouri, USA. Bird Conservation International 11, 113-128.

Thompson, S.J., Arnold, T.W., Amundson, C.L., 2014. A multiscale assessment of tree avoidance by prairie birds. Condor 116, 303-315.

TNC [The Nature Conservancy], 2008. Grand River Grasslands Conservation Action Plan (The Nature Conservancy).

Turner, M.G., 1989. Landscape ecology: the effect of pattern on process. Annual Review of Ecology, Evolution and Systematics 20,171-197.

US Department of Agriculture, 2011. USDA National Agriculture Imagery Program. Iowa Geographic Map Server. (Available at:) http://ortho.gis.iastate.edu/ (Accessed January 30, 2012).

Vickery, P.D., Tubaro, P.L., da Silva, J.M.C., Herkert, J.R., Cavalcanti, R.B., 1999. Conservation of grassland birds in the Western Hemisphere. In: Goriup, P.D., Herkert, J.R. (Eds.), Ecology and conservation of grassland birds of the Western Hemisphere. Studies in avian biology. Cooper Ornithological Society, Los Angeles, CA, USA, pp. 2-26.

Warren, T.L., Betts, M.G., Diamond, A.W., Forges, G.J., 2005. The influence of local habitat and landscape composition on cavity-nesting birds in a forested mosaic. For. Ecol. Manag. 214, 331-343.

Winter, M., Johnson, D.H., Shaffer, J.A., Donovan, T.M., Svedarsky, W.D., 2006. Patch size and landscape effects on density and nesting success of grassland birds. J. Wildl. Manag. 70, 158-172.

With, K., King, A.W., Jensen, W.E., 2008. Remaining large grasslands may not be sufficient to prevent grassland bird declines. Biology Conservation 141, 3152-3167.

Wuebbles, D.J., Hayhoe, K., 2004. Climate change projections for the United States Midwest. Mitig. Adapt. Strateg. Glob. Chang. 9, 335-363. 